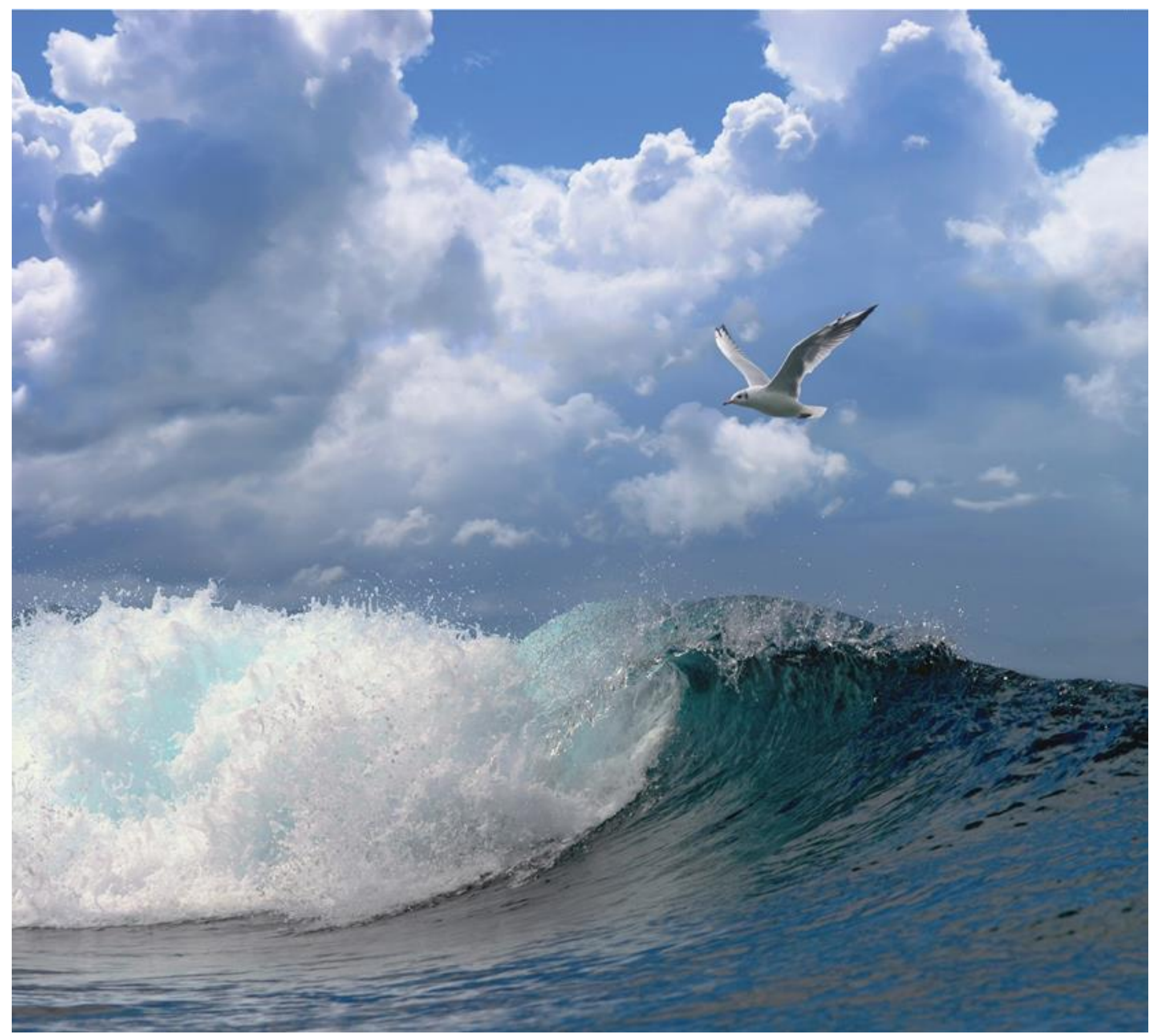

\title{
Marine mammal surveys in Dutch North Sea waters in 2018
}




\section{Marine mammal surveys in Dutch North Sea waters in 2018}

Authors: $\quad$ Steve CV Geelhoed, Nicole Janinhoff, Sander Lagerveld \& Hans (JP) Verdaat

Publication date: December 2018 
Keywords: abundance, aerial survey, distance sampling, distribution, harbour porpoise, Dutch Continental Shelf, North Sea, Phocoena phocoena, population size

Client: $\quad$ Anne-Marie Svoboda

Department of Nature and Biodiversity

Ministry of Agriculture, Nature and Food Quality

Bezuidenhoutseweg 73

2594 AC Den Haag

This report can be downloaded for free from https://doi.org/10.18174/466280

Wageningen Marine Research provides no printed copies of reports.

Wageningen Marine Research is ISO 9001:2015 certified.

(C) Wageningen Marine Research

Wageningen Marine Research, an institute Wageningen Marine Research accepts no liability for consequential damage, nor within the legal entity Stichting for damage resulting from applications of the results of work or other data Wageningen Research (a foundation under obtained from Wageningen Marine Research. Client indemnifies Wageningen Dutch private law) represented by $\mathrm{Dr}$. Marine Research from claims of third parties in connection with this application. M.C.Th. Scholten, Managing Director All rights reserved. No part of this publication may be reproduced and / or

KvK nr. 09098104 published, photocopied or used in any other way without the written permission WMR BTW nr. NL 8113.83.696.B16.

Code BIC/SWIFT address: RABONL2U IBAN code: NL 73 RABO 0373599285 


\section{Contents}

$\begin{array}{lr}\text { Summary } & 4\end{array}$

$1 \quad$ Introduction $\quad 5$

$2 \quad$ Assignment $\quad 6$

$3 \quad$ Materials and Methods $\quad 7$

$\begin{array}{lll}3.1 & \text { Study area, survey design and data acquisition } & 7\end{array}$

3.2 Data quality check and data storage $\quad 8$

3.3 Data analysis $\quad 8$

$\begin{array}{llr}\text { Results } & 10\end{array}$

$\begin{array}{lll}4.1 & \text { Weather conditions and survey effort } & 10\end{array}$

4.2 Harbour Porpoise sightings - pod size and behaviour 11

4.3 Harbour Porpoise - distribution 11

4.4 Harbour Porpoise - densities and abundance estimates $\quad 11$

4.5 Other marine mammals - sightings $\quad 12$

5 Discussion $\quad 16$

$\begin{array}{llr}6 & \text { Conclusions } & 18\end{array}$

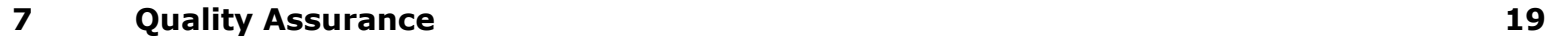

$8 \quad$ References $r$

$\begin{array}{lr}\text { Justification } & 22\end{array}$ 


\section{Summary}

In July 2018 aerial surveys to estimate the abundance of Harbour Porpoise Phocoena phocoena were conducted on the Dutch Continental Shelf. These surveys followed predetermined track lines in four areas: A - Dogger Bank, B - Offshore, C - Frisian Front \& D - Delta. Between 13 and 18 July the entire Dutch Continental Shelf (DCS) was surveyed.

Marine mammals were assessed using line transect distance sampling methods. Density and abundance estimates were calculated. In total, 309 sightings of 362 individual Harbour Porpoises were collected. Porpoise densities varied between 0.54-1.76 animals $/ \mathrm{km}^{2}$ in the areas A-D. The lowest densities $(0.54$ \& 0.63 animals $/ \mathrm{km}^{2}$ ) were found in areas D - Delta and A - Dogger Bank respectively. The highest density was found in area B - Offshore with 1.76 animals $/ \mathrm{km}^{2}$. Overall the average density on the Dutch Continental Shelf was 1.07 animals $/ \mathrm{km}^{2}$.

In July 2018, the total number of Harbour Porpoises on the Dutch Continental Shelf (areas A-D) was estimated at 63,514 animals ( $C I=34,276-119,7342)$. This estimates falls in the range of abundance estimates since 2010, with a minimum of 25,998 ( CI $=13,988-53,623$ in 2010) and a maximum of 76,773 ( $C I=43,414-154,265$ in 2014) individuals. The confidence intervals of the abundance estimates overlap, indicating no statistically significant differences between the years.

These abundance estimates show that up to a fifth of the North Sea population, estimated at 345,000361,000 individuals, has been present on the Dutch Continental Shelf during the summer surveys in 2010-2018.

The results of these aerial surveys will feed into the OSPAR MSFD indicator on abundance and distribution of marine mammals.

In total 25 sightings of other marine mammal species than Harbour Porpoises were recorded. These comprised 23 sightings of single seals (Grey Seal Halichoerus grypus and Harbour Seal Phoca vitulina). The majority of the seals was observed in coastal waters of the Wadden Isles. Two single Minke Whales Balaenoptera acutorostrata were seen in area B - Offshore, with another two off effort in the same area. One sighting of a pod of three White-beaked Dolphins Lagenorhynchus albirostris was made in area C Frisian Front.

This research is part of the project 'KRM monitoring bruinvis'. 


\section{Introduction}

In the Dutch Harbour Porpoise conservation plan (Camphuysen \& Siemensma, 2011) abundance estimates of the Dutch population of Harbour Porpoise Phocoena phocoena have been identified as one of the research needs with the highest priority. These assessments are needed to monitor the density and distribution of this protected species and could be used to evaluate potential impacts of anthropogenic activities on the national population level in the future.

Abundance estimates for the entire Dutch Continental Shelf were lacking until 2010. In July 2010-March 2011, under the umbrella of the Shortlist Masterplan Wind programme, dedicated aerial surveys of the entire Dutch Continental Shelf were conducted for the first time, in three different seasons (Geelhoed et al., 2011 \& 2013a). These surveys resulted in abundance estimates and distribution maps of Harbour Porpoises, thus providing a baseline for subsequent surveys in order to study annual and seasonal variations in the numbers and distribution of porpoises in Dutch waters.

As a follow-up, surveys of the Dutch Continental Shelf were conducted in spring 2012 (Geelhoed et al., 2013b), spring 2013 (Geelhoed et al., 2014a), summer 2014 (Geelhoed et al., 2014b), summer 2015 (Geelhoed et al., 2015), and summer 2017 (Geelhoed et al., 2018; Geelhoed \& Scheidat, 2018). In this report we present the results of the aerial surveys conducted in July 2018. It was the fifth time ever a complete dedicated survey of Dutch waters took place in July. These surveys are conducted under the umbrella of the KRM-project monitoring bruinvis, a continuation of the BO-project BO-11-011.04-004 funded by the Ministry of Economic Affairs of The Netherlands. Apart from aerial surveys this KRMproject contains diet studies, and studies on contaminant loads in stranded harbour porpoises. The results of these studies are published separately. 


\section{Assignment}

This report presents the aerial survey results using line transect distance sampling as described in the original assignment of KRM monitoring bruinvis, a continuation of the Beleidsondersteunend Onderzoek program of the Ministry of Economic Affairs. This assignment consisted of aerial surveys of marine mammals on the entire Dutch Continental Shelf in 2018. 


\section{Materials and Methods}

\subsection{Study area, survey design and data acquisition}

The study area included the entire Dutch section of the continental shelf $\left(59,417 \mathrm{~km}^{2}\right)$. The study area was divided into four sub-areas: A - Dogger Bank $\left(9,615 \mathrm{~km}^{2}\right), \mathrm{B}$ - Offshore $\left(16,892 \mathrm{~km}^{2}\right), \mathrm{C}$ - Frisian Front $\left(12,023 \mathrm{~km}^{2}\right)$ and D - Delta $\left(20,797 \mathrm{~km}^{2}\right)$ (Figure 1). The design of the track line set-up was chosen to be parallel in areas $C$ and $D$ and zigzag in area $A$ and $B$ to ensure a representative coverage of the sub-areas and minimize off effort time between track lines. In addition, the direction of track lines followed depth gradients in order to get a better sample by minimising variance in encounter rates between transect lines (Buckland et al., 2001). The survey design has been the same since the first aerial surveys were conducted in 2008 (Scheidat et al., 2012).

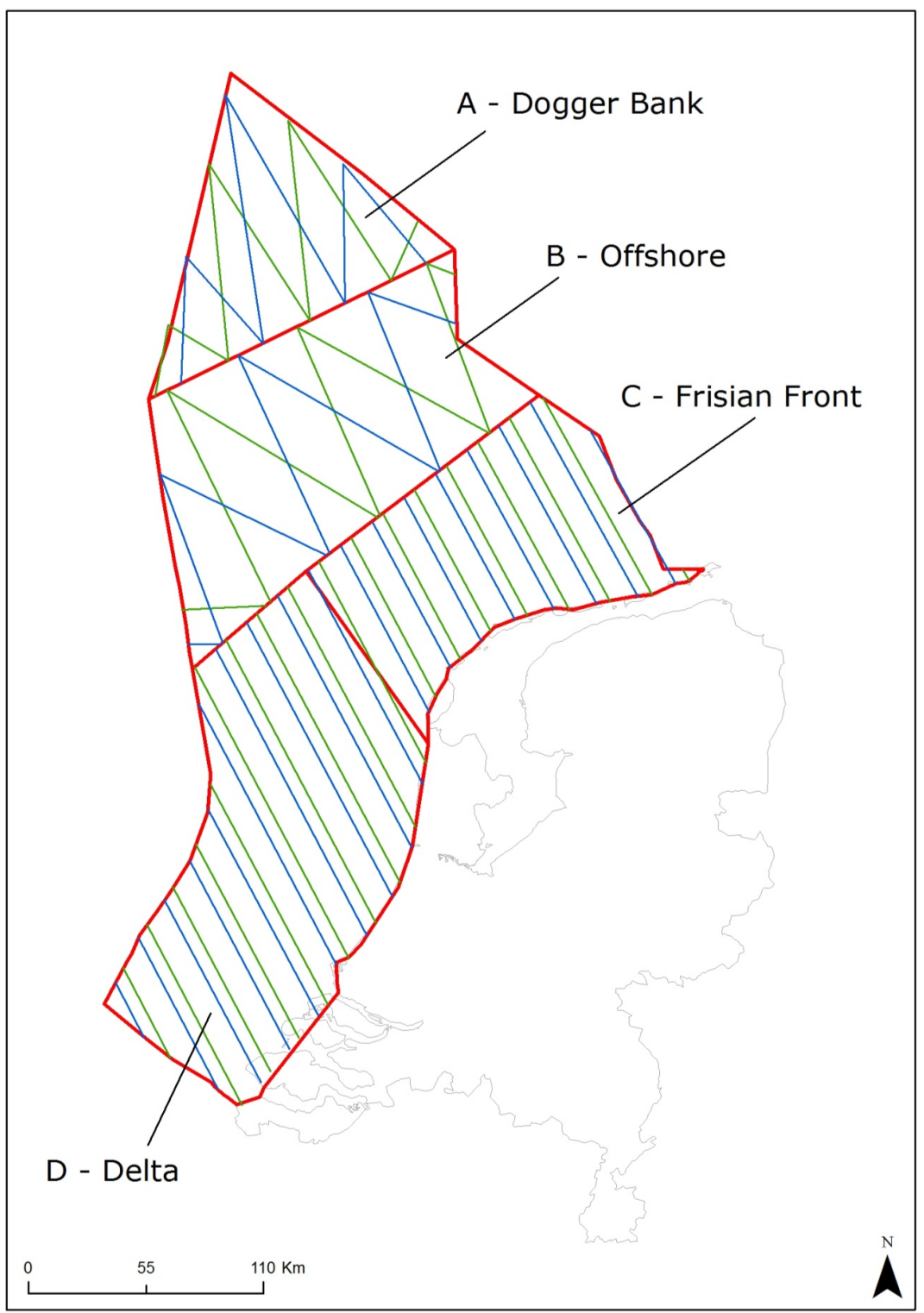

Figure 1. Map of the Dutch Continental Shelf with the planned track lines in study areas A - Dogger Bank, B Offshore, C - Frisian Front and D - Delta. Colours indicate sets of track lines.

Surveys were conducted with a Partenavia 68, a high-winged twin-engine airplane equipped with bubble

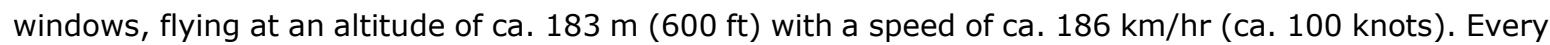
four seconds the aircraft's position and time (to the nearest second) were recorded automatically onto a laptop computer connected to a GPS. Surveys were conducted by a team of three people. Sighting 
information and details on environmental conditions were entered by one person (the navigator) at the beginning of each transect and whenever conditions changed. Observations were made by two dedicated observers located at the bubble windows on the left and right sides of the aircraft. For each observation the observers acquired sighting data including species (all cetaceans and seals), declination angle measured with an inclinometer from the aircraft abeam to the group, group size, presence of calves, behaviour (Table 1), swimming direction, cue, and reaction to the survey plane. The perpendicular distances from the transect to the sighting were later calculated from aircraft altitude and declination angle. Environmental data included sea state (Beaufort scale), turbidity (4 classes, assessed by visibility of objects below the sea surface), cloud cover (in octaves), glare and subjective sighting conditions (Table 2). These sighting conditions represent each observer's subjective view of the likelihood that the observer would see a harbour porpoise within the search area should one be present, and could differ between left and right.

Table 1. Behavioural codes and description for marine mammals.

\begin{tabular}{ll}
\hline Code & Behaviour \\
\hline Sw & directional swimming \\
Fasw & fast directional swimming or porpoising \\
Mill & milling, non-directional swimming \\
Rest & resting/logging: not moving at the surface \\
Feed & Feeding \\
Headup & spyhop of seals vertically in the water column \\
Other & other behaviour, noted down in comments \\
\hline
\end{tabular}

Table 2. Description of subjective sighting conditions.

\begin{tabular}{ll}
\hline Sighting condition & Description \\
\hline Good $(G)$ & $\begin{array}{l}\text { Observer's assessment that the likelihood of seeing a porpoise, should one } \\
\text { occur within the search area, is good. Normally, good subjective conditions } \\
\text { will require a sea state of two or less and a turbidity of less than two. } \\
\text { Observer's assessment that the likelihood of seeing a porpoise, should one } \\
\text { Occur within the searching area, is moderate. } \\
\text { Observer's assessment that it is unlikely to see a porpoise, should one occur } \\
\text { Poor }(\mathrm{P})\end{array}$ \\
$\begin{array}{l}\text { Not possible to } \\
\text { observe }(X)\end{array}$ & Observer off effort due to adverse circumstances \\
\end{tabular}

Surveys were conducted in weather conditions safe for flying operations (no fog or rain, visibility $>3 \mathrm{~km}$ ) and suitable for porpoise surveys (Beaufort sea state equal or less than 3). Surveys were conducted by Steve Geelhoed, Nicole Janinhoff and Hans Verdaat as observer and navigator. Peter Reijnhout was the pilot.

\subsection{Data quality check and data storage}

All collected data was checked, e.g. for consistency of codes, corrected and subsequently stored in the Dutch database.

\subsection{Data analysis}

The survey data were collected using distance sampling techniques (Buckland et al., 2001; 2004). The collected sightings are used to calculate densities and abundance estimates, and to produce distribution maps. Only data from transect lines flown in good or moderate conditions were used in the analyses. Densities and abundance estimates were calculated according to distance sampling methods, that yield absolute densities, i.e., the number of animals $/ \mathrm{km}^{2}$ with the associated $95 \%$ confidence interval (CI) and coefficient of variation (CV; Buckland et al., 2001). To do this the so called effective strip half-width (ESW) is calculated. The ESW is calculated for each side of the track line separately. To obtain the first 
component to calculate the ESW the perpendicular distance of a sighting to the track line is measured. To calculate the distance of the sighting to the track line from air, the plane's altitude $(600$ feet $=183 \mathrm{~m}$ ) and the vertical or 'declination' angle to the animal are used. The latter is measured when it comes (or is estimated to come) abeam. By modelling a detection curve to all these distances the effective strip half-width is obtained; this is defined as the distance at which the expected number of detected objects would be the same as for the actual survey (Buckland et al., 2001).

One of the assumptions of line-transect distance sampling is that all animals on the track line are detected, which would mean that the chance to see all animals at a distance of $0 \mathrm{~m}$ from the track line is $1(100 \%)$. For most animals, but in particular for cetaceans, this assumption is not true and a correction factor, called $\mathrm{g}(0)$, needs to be obtained to correct for the proportion of animals missed on the track line. In practice there are two reasons why animals are not recorded: 1 . the animals are not "available" to be seen, (e.g. because they are sub-merged) or 2. they are missed by the observers ("observer bias"). To obtain a reliable estimate of absolute abundance (the number of animals in a given area e.g., the DCS) it is therefore needed to estimate the proportion of animals actually seen on the track line: the true value of $\mathrm{g}(0)$, and use the reciprocal of this value to correct the ESW. In the analysis $\mathrm{g}(0)$ values of 0.37 for good conditions and 0.14 for moderate conditions are used (taken from Scheidat et al., 2008).

Animal abundance in each stratum v (sub-areas A, B, C and D) was estimated using a HorvitzThompson-like estimator (Buckland et al., 2001; 2004) as follows:

$$
\hat{N}_{v}=\frac{A_{v}}{L_{v}}\left(\frac{n_{\mathrm{gs} v}}{\hat{\mu}_{\mathrm{g}}}+\frac{n_{\mathrm{ms} v}}{\hat{\mu}_{\mathrm{m}}}\right) \bar{s}_{v}
$$

where $A v$ is the area of the stratum, $L_{v}$ is the length of transect line covered on-effort in good or moderate conditions, $\mathrm{n}_{\mathrm{gsv}}$ is the number of sightings that occurred in good conditions in the stratum, $\mathrm{n}_{\mathrm{msv}}$ is the number of sightings that occurred in moderate conditions in the stratum, $\mu_{\mathrm{g}}$ is the estimated total effective strip width in good conditions, $\mu_{\mathrm{m}}$ is the estimated total effective strip width in moderate conditions and $\bar{S}_{v}$ is the mean observed school size in the stratum.

Group abundance by stratum was estimated by $\quad \hat{N}_{v(\text { group })}=\hat{N}_{v} / \bar{S}_{v}$

Total animal and group abundances of the entire Dutch Continental Shelf were estimated by:

$$
\hat{N}=\sum_{v} \hat{N}_{v} \quad \text { and } \quad \hat{N}_{\text {(group) }}=\sum_{v} \hat{N}_{v \text { (group) }}
$$

respectively. Densities were estimated by dividing the abundance estimates by the area of the associated stratum. Average group size across strata was estimated by $E[s]=N / N_{\text {(group) }}$. Coefficients of variation (CV) and 95\% confidence intervals (CI) were estimated by a non-parametric bootstrap (999 replicates) within strata, using transect segments as the sampling units. The variance due to estimation of ESW was incorporated using a parametric bootstrap procedure which assumes the ESW estimates to be normally distributed random variables. More details on this method can be found in Scheidat et al. (2008; 2012).

Distribution maps were created by calculating densities per 1/9 ICES grid cell. This 1/9 ICES grid has latitudinal rows at intervals of 10', and longitudinal columns at intervals of 20'. ICES $1 / 9$ rectangles intersecting with the DCS measure approximately 20x20km, resulting in areas ranging from 388 to 409 $\mathrm{km}^{2}$, depending on latitude.

Densities per 1/9 ICES grid cell were calculated by dividing the total number of animals observed during good and moderate conditions by the total surveyed area. The surveyed area is the distance travelled multiplied by the total effective strip width (ESW). The effective strip half-width (ESW corrected for $g(0)$ values) was defined as $76.5 \mathrm{~m}$ for good sighting conditions and $27 \mathrm{~m}$ for moderate sighting conditions on each side of the track line (Gilles et al., 2009; Scheidat et al., 2008). Densities in grid cells extending outside the borders of the surveyed area (e.g., the Wadden Sea) could be less reliable due to lower effort and habitat discontinuities within the grid cell. Grid cells with an effort less than $1 \mathrm{~km}^{2}$ were omitted from the density calculations. 


\section{Results}

\subsection{Weather conditions and survey effort}

The entire Dutch Continental Shelf was surveyed on five days in the period 13-18 July (Figure 2, Table 3), resulting in a total distance of $3039.8 \mathrm{~km}$ on effort. Of this distance $79.5 \%$ was surveyed with good or moderate conditions on at least one side of the plane (Table 4). Some of the track lines in Area A Dogger Bank and Area B - Offshore with poor or worse conditions on 15 July were surveyed again under better sighting conditions.
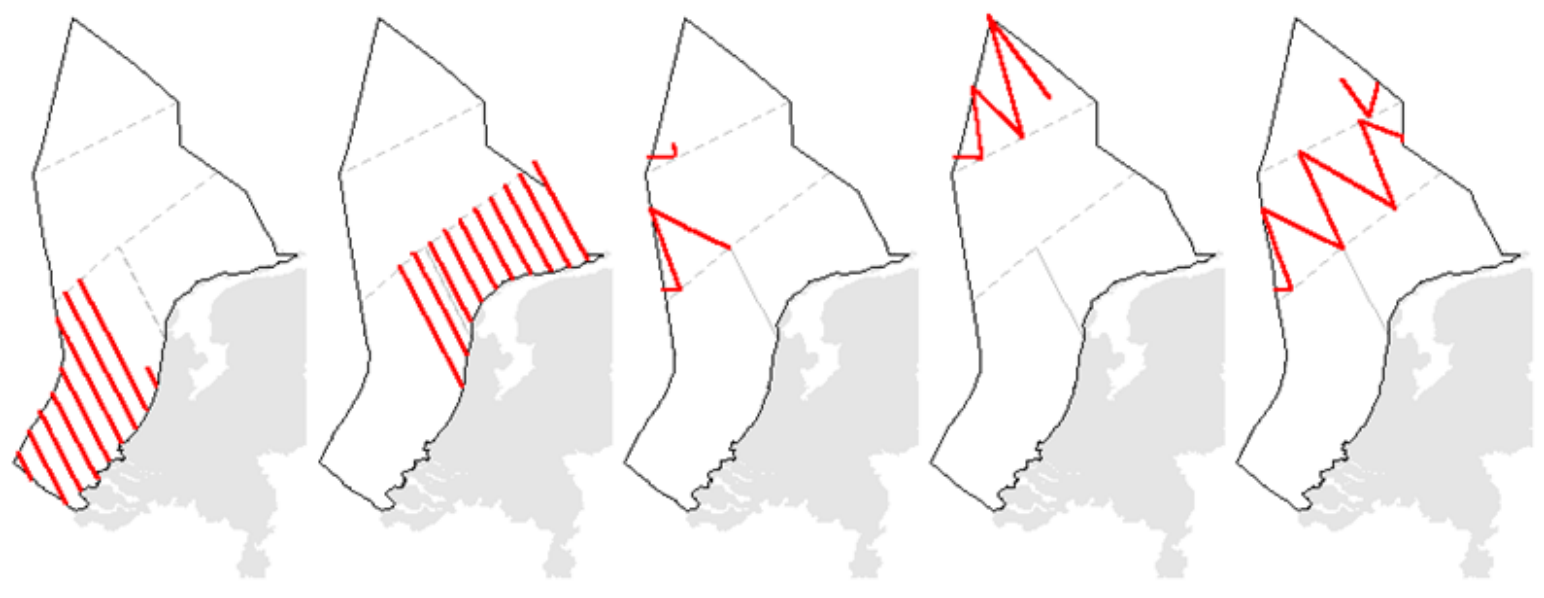

Figure 2. Survey effort per day July 2018.

Table 3. Survey dates and surveyed areas in July 2018.

\section{Survey date}

13 July

14July

15 July

17 July

18 July

\section{Surveyed area}

Area D - Delta

Area C - Frisian Front \& Area D - Delta

Area A - Dogger Bank \& Area B - Offshore

Area A - Dogger Bank

Area A - Dogger Bank \& Area B - Offshore

Table 4. Total survey days, effort (surveyed distance), sighting conditions ( $g$ - good, $m$ - moderate, $p-$ poor, $x$ - not possible to observe) and Harbour Porpoise sightings on both sides during the aerial surveys. Navigator sightings are excluded.

\begin{tabular}{|c|c|c|c|c|c|c|}
\hline \multirow{2}{*}{ Effort (km) } & \multicolumn{3}{|c|}{ Sighting conditions ( $\%$ ) } & \multicolumn{3}{|c|}{ Harbour Porpoise sightings (n) } \\
\hline & G & $\mathbf{m}$ & $\mathbf{p} / \mathbf{x}$ & Sightings & Individuals & 'Calves' \\
\hline 3039.8 & 14.1 & 65.3 & 20.5 & 309 & 362 & 23 \\
\hline
\end{tabular}




\subsection{Harbour Porpoise sightings - pod size and behaviour}

In total, 309 sightings with 362 individual Harbour Porpoises, including 23 calves, were collected (Table 4). These sightings are shown in Figure 3. Most sightings concerned single individuals, with an average pod size of 1.2 individuals. The maximum pod size was 5 animals, recorded twice.

The majority of the sightings concerned directionally swimming animals (83\%, $\mathrm{n}=297) ; 12 \%$ was milling or resting at the surface. Seven animals were qualified as feeding, associated with a fish ball, and feeding seabirds. Noteworthy is the observation of a Harbour Porpoise apparently giving birth in area B - Offshore on 18 July 2018.

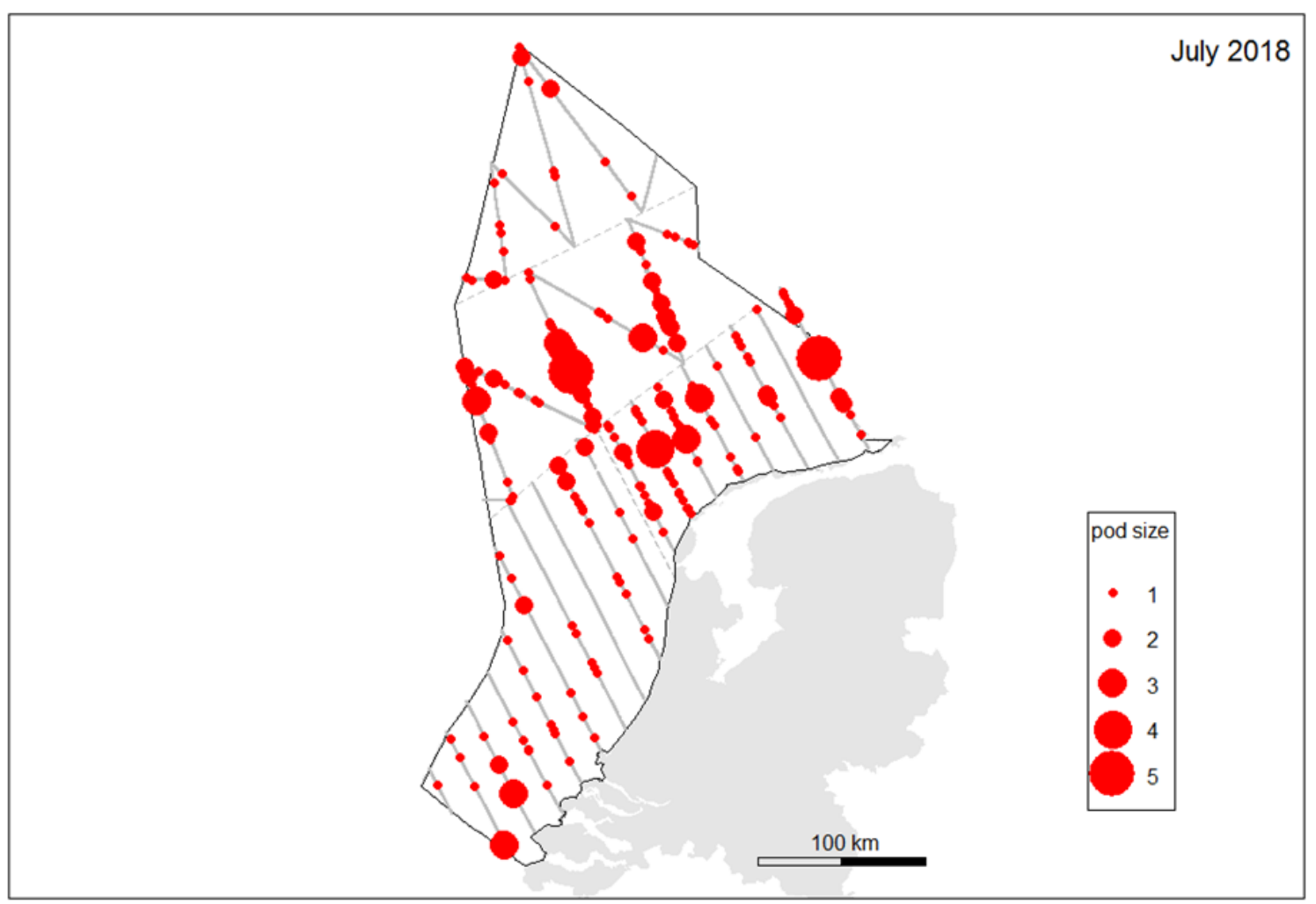

Figure 3. Harbour Porpoise sightings during the DCS survey in July 2018.

\subsection{Harbour Porpoise - distribution}

The distribution of porpoises (animals $/ \mathrm{km}^{2}$ ) per $1 / 9$ ICES grid cell is shown in Figure 4 . Harbour Porpoises were widely distributed and showed a homogenous distribution in a band from area D - Delta north to area B - offshore. The highest densities were found NW of the Wadden Isles. Harbour Porpoises were virtually absent in large areas in the eastern part of area A - Dogger Bank, and in the western part of area D - Delta.

\subsection{Harbour Porpoise - densities and abundance estimates}

Densities of Harbour Porpoises were estimated for each survey stratum (areas A-D) as well as for the whole DCS. Table 5 gives an overview of density (animals $/ \mathrm{km}^{2}$ ) as well as abundance (number of animals) per survey area. The overall density was 1.07 animals $/ \mathrm{km}^{2}$. The lowest densities $(0.54 \& 0.63$ animals $/ \mathrm{km}^{2}$ ) were found in areas D - Delta and A - Dogger Bank respectively. The highest density was found in area B - Offshore with 1.76 animals $/ \mathrm{km}^{2}$ (Table 5). 
The total number of Harbour Porpoises on the Dutch Continental Shelf (areas A-D) was estimated at 63,514 animals ( $C I=34,276-119,7342$, Table 5 ) in July 2018 . The majority of the animals $(72.9 \%)$ was estimated in areas B - Offshore and C - Frisian Front, both areas covering less than half of the total area of the DCS.

Table 5. Abundance estimates of Harbour Porpoises for July 2018 per area.

\begin{tabular}{lccccc}
\hline & $\begin{array}{c}\text { Density } \\
\text { (animals } / \mathbf{k m}^{\mathbf{2}} \text { ) }\end{array}$ & $\mathbf{9 5 \%} \mathbf{C I}$ & $\begin{array}{c}\text { Abundance } \\
\text { (n animals) }\end{array}$ & $\mathbf{9 5 \%} \mathbf{~ C I}$ & CV \\
\hline Area A - Dogger Bank & 0.63 & $0.30-1.43$ & 6020 & $2859-13,704$ & 0.41 \\
Area B - Offshore & 1.76 & $0.87-3.44$ & 29,722 & $14,663-58,170$ & 0.36 \\
Area C - Frisian Front & 1.38 & $0.63-2.84$ & 16,595 & $7618-34,120$ & 0.37 \\
Area D - Delta & 0.54 & $0.26-1.06$ & 11,176 & $5400-22,078$ & 0.35 \\
\hline Total DCS & 1.07 & $0.58-2.02$ & 63,514 & $34,276-119,734$ & 0.32 \\
\hline
\end{tabular}

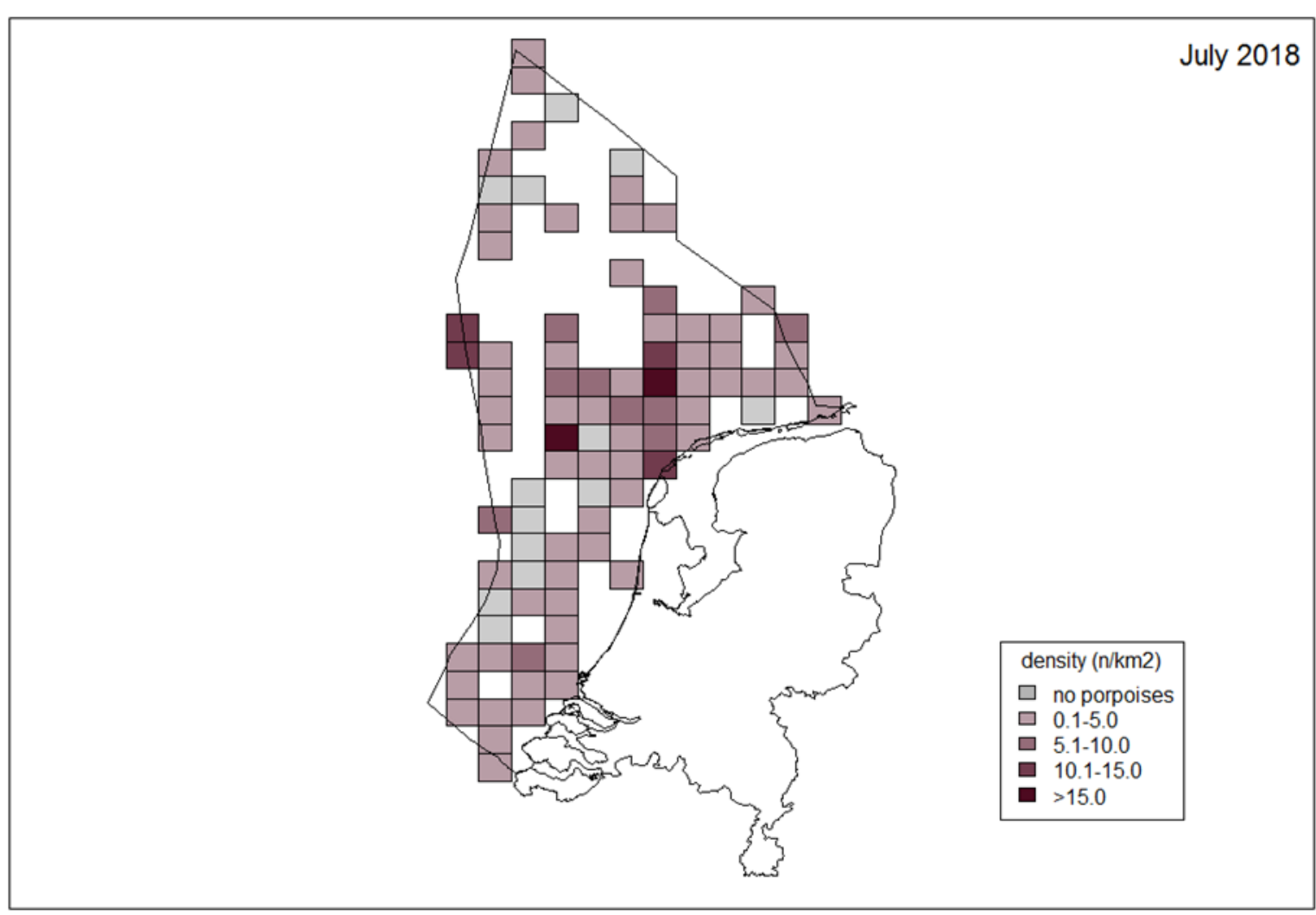

Figure 4. Density distribution of Harbour Porpoises (animals $/ \mathrm{km}^{2}$ ) per 1/9 ICES grid cell, July 2018. Grid cells with low effort $(<1 \mathrm{~km} 2)$ are omitted.

\subsection{Other marine mammals - sightings}

During the surveys 26 sightings of other marine mammal species were made on effort (Table 6). Two other cetacean species than Harbour Porpoise were sighted: Minke Whale Balaenoptera acutorostrata., and White-beaked Dolphin Lagenorhynchus albirostris. Two Minke Whales were seen in the northeastern part of area B - Offshore (Figure 5). Off effort two more sightings of single animals were made in this area, where several fish balls and feeding seabirds were present. One small pod of White-beaked Dolphins was seen 14 July in area C - Frisian Front (Figure 6). Seals (Grey Seal Halichoerus grypus and Harbour Seal Phoca vitulina) were seen in all areas, but the majority was seen in the vicinity of the coast, with a concentration north of the Wadden Isles near their haul out sites (Figure 7). Most seals were not identified to species level, but Grey Seals $(n=4)$ were seen in Areas C - Frisian Front and A 
- Dogger Bank, whereas Harbour Seals $(n=6)$ were seen in areas C- Frisian Front and D - Delta. Numbers of seals and Minke Whale were too low to calculate densities and abundance estimates.

Table 6. Total survey days, effort (surveyed distance), and on effort sightings of marine mammals other than Harbour Porpoise during the aerial surveys.

\begin{tabular}{|c|c|c|c|c|c|c|}
\hline \multirow{2}{*}{$\begin{array}{l}\text { Effort } \\
(\mathrm{km})\end{array}$} & \multicolumn{2}{|c|}{ Minke Whale } & \multicolumn{2}{|c|}{ White-beaked Dolphin } & \multicolumn{2}{|l|}{ Seals } \\
\hline & Sightings & $\mathbf{N}$ & Sightings & $\mathbf{N}$ & Sightings & $\mathbf{N}$ \\
\hline 3039.8 & 2 & 2 & 1 & 3 & 23 & 23 \\
\hline
\end{tabular}

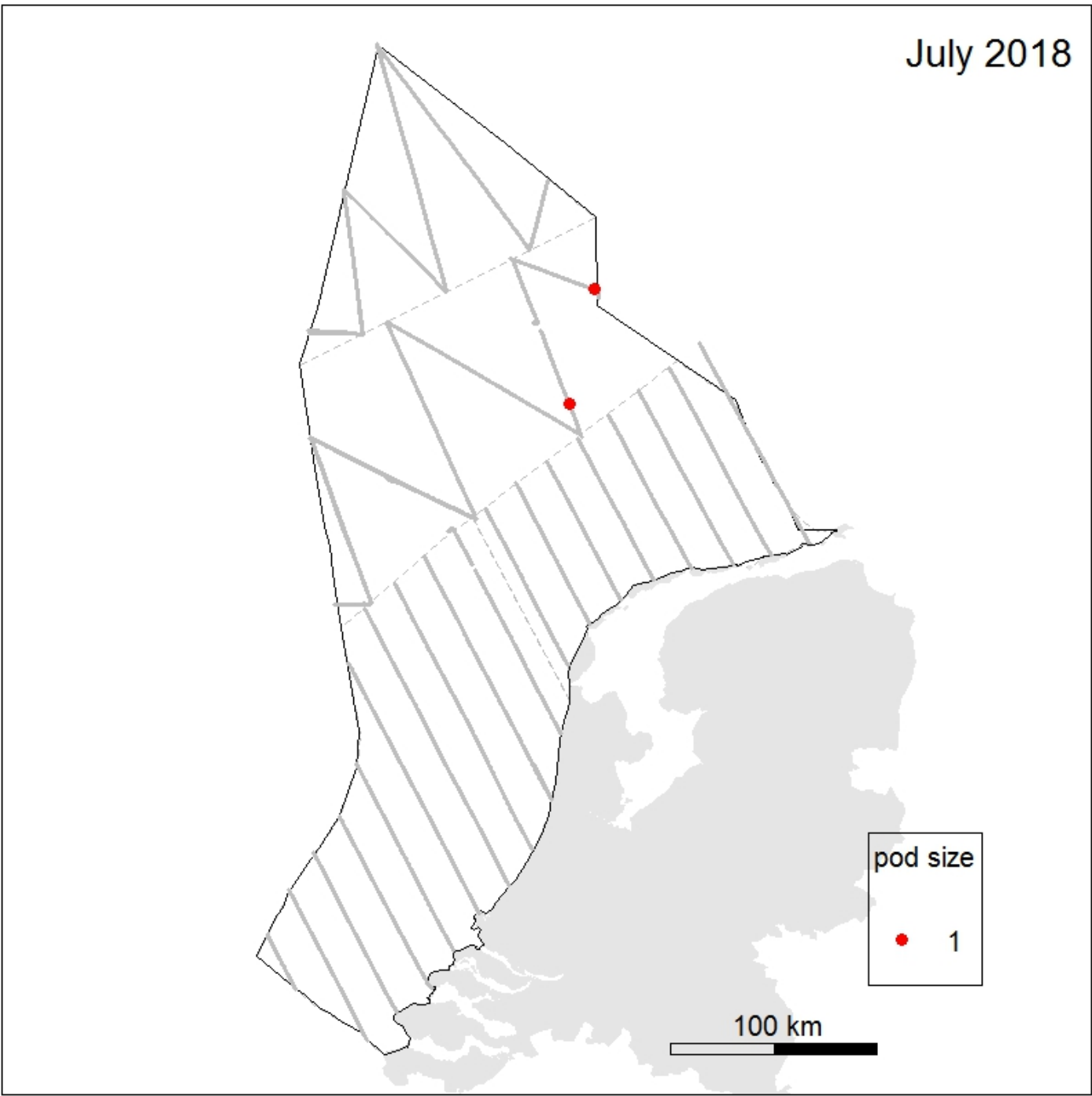

Figure 5. Minke whale sightings during the DCS survey in July 2018. 


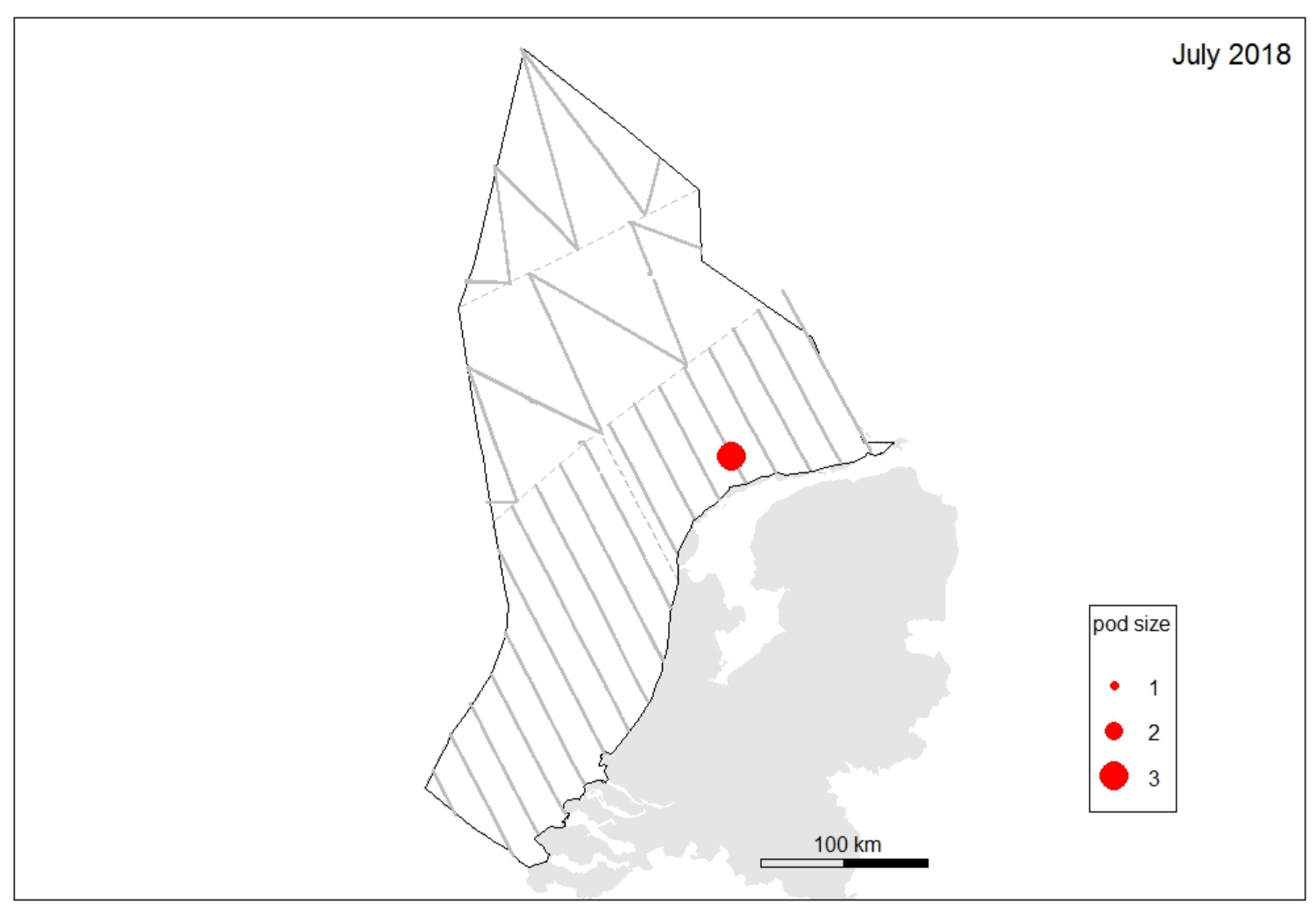

Figure 6. White-beaked Dolphin sightings during the DCS survey in July 2018. 


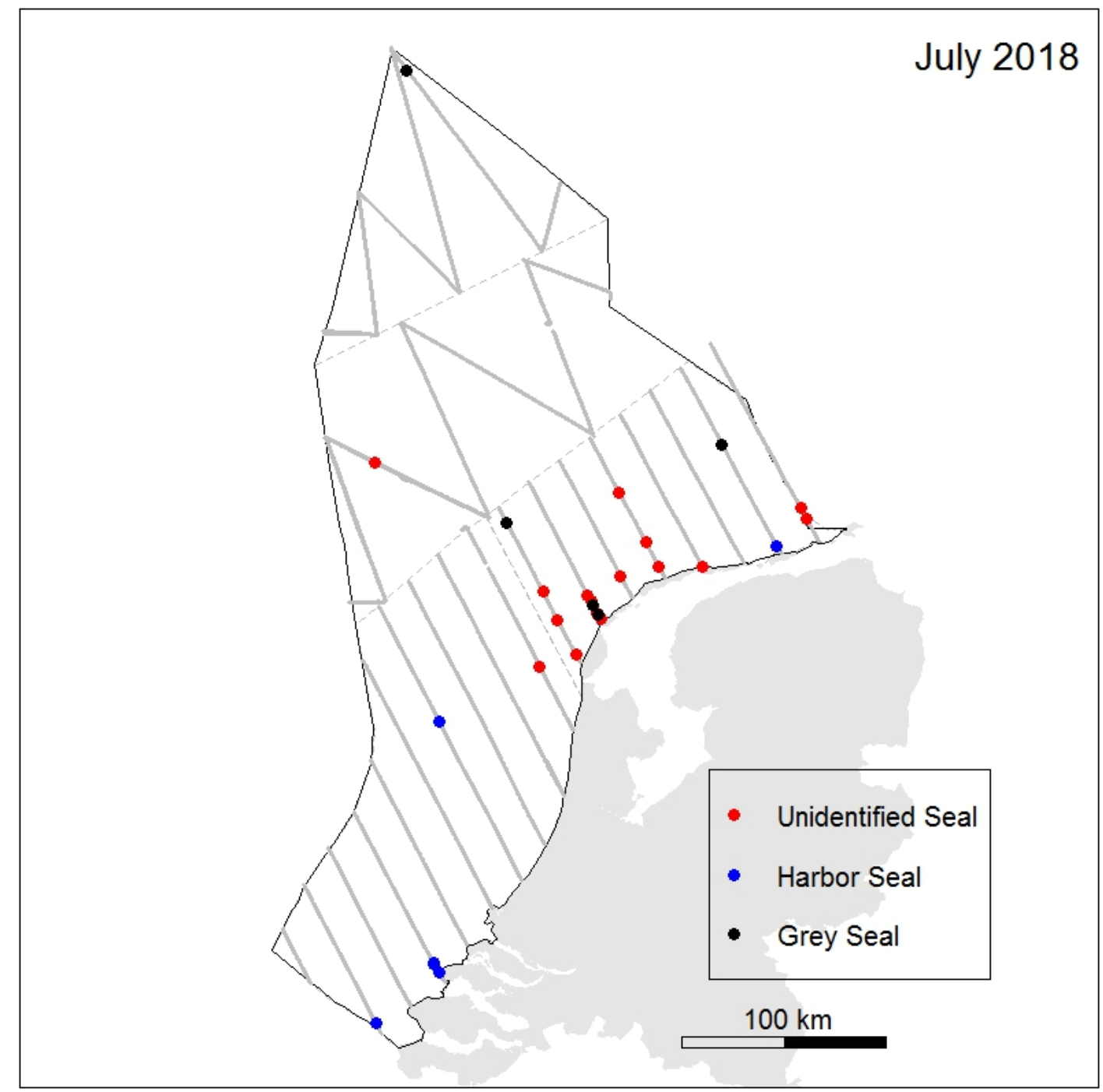

Figure 7. Seal sightings during the DCS survey in July 2018. 


\section{Discussion}

Wageningen Marine Research and its predecessor IMARES have been conducting aerial surveys in Dutch North Sea waters since May 2008. Four DCS wide surveys have been conducted previously in the month of July, in 2010, 2014, 2015 and 2017. Densities and abundance estimates of Harbour Porpoises are presented in Table 7, showing that summer densities vary between 0.14 and 3.08 animals $/ \mathrm{km}^{2}$ in the different years, highlighting that the density between the sub-areas is highly variable.

Table 7. Density and abundance estimates of Harbour Porpoises obtained in July 2010-2018 (Geelhoed et al. 2011, 2013a, 2014b. 2018, Geelhoed \& Scheidat 2018).

\begin{tabular}{|c|c|c|c|c|c|}
\hline 2018 & $\begin{array}{c}\text { Density } \\
\left(\text { animals } / \mathbf{k m}^{2}\right)\end{array}$ & C95\% CI & $\begin{array}{l}\text { Abundance } \\
\text { (n animals) }\end{array}$ & $95 \% \mathrm{CI}$ & $\mathbf{C V}$ \\
\hline Area A - Dogger Bank & 0.63 & $0.30-1.43$ & 6020 & $2859-13,704$ & 0.41 \\
\hline Area B - Offshore & 1.76 & $0.87-3.44$ & 29,722 & $14,663-58,170$ & 0.36 \\
\hline Area C - Frisian Front & 1.38 & $0.63-2.84$ & 16,595 & $7618-34,120$ & 0.37 \\
\hline Area D - Delta & 0.54 & $0.26-1.06$ & 11,176 & $5400-22,078$ & 0.35 \\
\hline Total DCS & 1.07 & $0.58-2.02$ & 63,514 & $34,276-119,734$ & 0.32 \\
\hline \multicolumn{6}{|l|}{2017} \\
\hline Area A - Dogger Bank & 0.14 & $0.01-0.29$ & 1325 & $167-2833$ & 0.46 \\
\hline Area B - Offshore & 1.28 & $0.55-2.92$ & 21,584 & $9229-49,331$ & 0.44 \\
\hline Area C - Frisian Front & 0.53 & $0.08-1.53$ & 6360 & $991-18,402$ & 0.64 \\
\hline Area D - Delta & 0.85 & $0.41-1.66$ & 17,631 & $8595-34,552$ & 0.37 \\
\hline Total DCS & 0.79 & $0.41-1.86$ & 46,902 & $24,389-93,532$ & 0.35 \\
\hline \multicolumn{6}{|l|}{2015} \\
\hline Area A - Dogger Bank & 1.12 & $0.43-2.25$ & 10,748 & $4113-21,676$ & 0.39 \\
\hline Area B - Offshore & 0.80 & $0.17-1.20$ & 13,573 & $7002-26,606$ & 0.35 \\
\hline Area C - Frisian Front & 0.44 & $0.20-0.98$ & 5304 & $2354-11,798$ & 0.43 \\
\hline Area D - Delta & 0.56 & $0.41-1.58$ & 11,674 & $3542-24,958$ & 0.45 \\
\hline Total DCS & 0.70 & $0.36-1.34$ & 41,299 & $21,194-79,256$ & 0.33 \\
\hline \multicolumn{6}{|l|}{2014} \\
\hline Area A - Dogger Bank & 3.08 & $1.50-6.45$ & 29,689 & $14,375-61,995$ & 0.37 \\
\hline Area B - Offshore & 0.37 & $0-1.21$ & 6297 & $0-20,509$ & 0.96 \\
\hline Area C - Frisian Front & 1.83 & $0.97-4.11$ & 22,010 & $11,623-49,439$ & 0.39 \\
\hline Area D - Delta & 0.90 & $9.46-1.84$ & 18,778 & $9548-38,167$ & 0.36 \\
\hline Total DCS & 1.29 & $0.73-2.60$ & 76,773 & $43,414-154,265$ & 0.34 \\
\hline \multicolumn{6}{|l|}{2010} \\
\hline Area A - Dogger Bank & 0.40 & $0.18-0.85$ & 3806 & $1738-8165$ & 0.40 \\
\hline Area B - Offshore & 0.48 & $0.21-1.06$ & 8055 & $3589-17,872$ & 0.42 \\
\hline Area C - Frisian Front & 0.34 & $0.05-0.89$ & 4039 & $553-10,701$ & 0.62 \\
\hline Area D - Delta & 0.48 & $0.21-1.06$ & 10,098 & $4341-22,024$ & 0.40 \\
\hline Total DCS & 0.44 & $0.24-0.90$ & 25,998 & $13,988-53,623$ & 0.34 \\
\hline
\end{tabular}

The abundance estimate for the DCS in 2018 of 63,514 individuals (CI $=34,276-119,734$ ) lies between the minimum estimate in $2010(n=25,998 ; C I=13,988-53,623)$ and the maximum estimate in 2014 ( $n=76,773 ; C I=43,414-154,265)$. Neither the DCS abundance estimate, nor the abundance estimates per sub-area show a trend. The confidence intervals of the abundance estimates overlap, indicating no statistically significant differences between the years. 
The porpoises in Dutch waters belong to the population that uses the wider North Sea (Evans et al 2009). This whole area was surveyed during summer of 2005 and 2016 (SCANS-II and SCANS-III), resulting in an abundance estimate of 355.000 or 345.000 individuals respectively (Hammond et al., 2013, 2017). Using a model-based approach, with the SCANS data and national surveys, Gilles et al. (2016) estimated the population size to number 361,000 individuals in 2005-2013. Putting this in relationship with the results from the DCS surveys indicates that up to a fifth of the North Sea population has been present on the Dutch Continental Shelf in summer 2010-2018. 


\section{Conclusions}

An aerial survey of the Dutch Continental Shelf in July 2018 resulted in an abundance estimate of 63,514 animals $(C I=34,276-119,734)$. This estimate falls in the range of abundance estimates since 2010, with a minimum of 25,998 ( CI = 13,988 - 53,623 in 2010) and a maximum of 76,773 (CI = 43,414154,265 in 2014) individuals. The confidence intervals of the abundance estimates overlap, indicating no statistically significant differences between the years.

These abundance estimates show that up to a fifth of the North Sea population, estimated at 345,000361,000 individuals, has been present on the Dutch Continental Shelf during the summer surveys in 2010-2018.

The results of these aerial surveys will feed into the OSPAR MSFD indicator on abundance and distribution of marine mammals. 


\section{Quality Assurance}

Wageningen Marine Research utilises an ISO 9001:2008 certified quality management system (certificate number: 187378-2015-AQ-NLD-RvA). This certificate is valid until 15 September 2018. The organisation has been certified since 27 February 2001. The certification was issued by DNV Certification B.V. 


\section{References}

Buckland ST, Anderson DR, Burnham KP, Laake JL, Borchers DL \& Thomas L, 2001. Introduction to Distance Sampling, Vol. Oxford University Press, Oxford.

Buckland ST, Anderson DR, Burnham KP, Laake JL, Borchers DL \& Thomas L, 2004. Advanced distance sampling. Oxford University press, New York, USA.

Camphuysen CJ \& Siemensma ML, 2011. Conservation plan for the Harbour Porpoise Phocoena phocoena in The Netherlands: towards a favourable conservation status. NIOZ Report 2011-07, Royal Netherlands Institute for Sea Research, Texel.

Evans P, Andersen LW, Bjørge A, Fontaine M, Galatius A, Kinze CC, Lockyer C, De Luna C, Pierce GJ, Sveegaard S, Teilmann J, Tiedemann R \& Walton M, 2009. Harbour porpoise Phocoena phocoena. Report of ASCOBANS/HELCOM small cetacean population structure workshop, 8-10 October 2007. UN Campus, Bonn, Germany.

Geelhoed S, Scheidat M, Aarts G, van Bemmelen R, Janinhoff N, Verdaat H \& Witte R, 2011. Shortlist Masterplan Wind - Aerial surveys of harbour porpoises on the Dutch Continental Shelf. Research Report IMARES Wageningen UR - Institute for Marine Resources \& Ecosystem Studies, Report No. C103/11.

Geelhoed SCV, Scheidat M, van Bemmelen RSA \& Aarts G, 2013a. Abundance of harbour porpoises (Phocoena phocoena) on the Dutch Continental Shelf, aerial surveys in July 2010-March 2011. Lutra 56(1): 45-57.

Geelhoed SCV, Scheidat M, \& van Bemmelen R, 2013b. Marine mammal surveys in Dutch waters in 2012. Research Report IMARES Wageningen UR - Institute for Marine Resources \& Ecosystem Studies, Report No. C038/13.

Geelhoed SCV, Scheidat M, \& van Bemmelen RSA, 2014a. Marine mammal surveys in Dutch waters in 2013. Research Report IMARES Wageningen UR - Institute for Marine Resources \& Ecosystem Studies, Report No. C027/14.

Geelhoed SCV, Lagerveld S, Verdaat JP \& Scheidat M, 2014b. Marine mammal surveys in Dutch waters in 2014. Research Report IMARES Wageningen UR - Institute for Marine Resources \& Ecosystem Studies, Report No. C180/14.

Geelhoed SCV, Lagerveld S \& Verdaat JP, 2015. Marine mammal surveys in Dutch North Sea waters in 2015. Research Report IMARES Wageningen UR - Institute for Marine Resources \& Ecosystem Studies, Report No. C189/15.

Geelhoed SCV, Janinhoff N, Lagerveld S, Lehnert LS \& Verdaat JP, 2018. Marine mammal surveys in Dutch North Sea waters in 2017. Wageningen Marine Research (University \& Research centre), Wageningen Marine Research report C030/18.

Geelhoed SCV \& Scheidat M, 2018. Abundance of harbour porpoises (Phocoena phocoena) on the Dutch Continental Shelf, aerial surveys 2012-2017. Lutra 61(1): 127-136.

Gilles A, Scheidat M \& Siebert U, 2009. Seasonal distribution of harbour porpoises and possible interference of offshore wind farms in the German North Sea. Marine Ecology-Progress Series 383: 295-307.

Gilles A, Viquerat S, Becker EA, Forney KA, Geelhoed SCV, Haelters J, Nabe-Nielsen J, Scheidat M, Siebert U, Sveegaard S, van Beest FM, van Bemmelen R \& Aarts G, 2016. Seasonal habitatbased density models for a marine top predator, the harbor porpoise, in a dynamic environment. Ecosphere7 (6):e01367. 10.1002/ecs2.1367

Hammond PS, Macleod K, Berggren P, Borchers DL, Burt ML, Cañadas A, Desportes G, Donovan GP, Gilles A, Gillespie D, Gordon J, Hedley S, Hiby L, Kuklik I, Leaper R, Lehnert K, Leopold M, Lovell $P$, Øien N, Paxton C, Ridoux V, Rogan E, Samarra F, Scheidat M, Sequeira M, Siebert U, Skov H, Swift R, Tasker ML, Teilmann J, Van Canneyt O \& Vázquez JA, 2013. Cetacean abundance and distribution in European Atlantic shelf waters to inform conservation and management. Biological Conservation, 164: 107-122.

Hammond PS, Lacey C, Gilles A, Viquerat S, Börjesson P, Herr H, Macleod K, Ridoux V, Santos MB, Scheidat M, Teilmann J, Vingada J \& Øien N, 2017. Estimates of cetacean abundance in European Atlantic waters in summer 2016 from the SCANS-III aerial and shipboard surveys. 
SCANS, 2008. Small Cetaceans in the European Atlantic and North Sea. Final report to the European Commission under project LIFE04NAT/GB/000245. Available from SMRU, Gatty Marine Laboratory, University of St. Andrews, St. Andrews, Fife, UK.

Scheidat M, Gilles A, Kock K \& Siebert U, 2008. Harbour porpoise Phocoena phocoena abundance in the south-western Baltic Sea. Endangered Species Research 5: 215-223.

Scheidat M, Verdaat H \& Aarts G, 2012. Using aerial surveys to estimate density and distribution of harbour porpoises in Dutch waters. Journal of Sea Research 69: 1-7. 


\section{Justification}

Report C098/18

Project Number: 4312100087

The scientific quality of this report has been peer reviewed by a colleague scientist and a member of the Management Team of Wageningen Marine Research

Approved: $\quad$ Meike Scheidat

Senior researcher

Wageningen Marine Research

Signature:

Date: $\quad 11$ December 2018

Approved: Jakob Asjes

Manager Integration

Wageningen Marine Research

Signature:

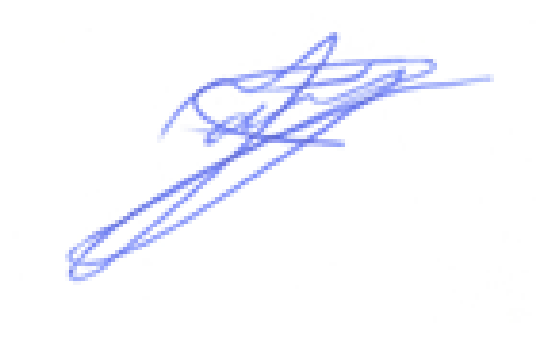

Date:

11 December 2018 
Wageningen Marine Research

T +31 (0)317480900

E: marine-research@wur.nl

www.wur.eu/marine-research

Visitors' address

- Ankerpark 271781 AG Den Helder

- Korringaweg 7, 4401 NT Yerseke

- Haringkade 1, 1976 CP IJmuiden
Wageningen Marine Research is the Netherlands research institute established to provide the scientific support that is essential for developing policies and innovation in respect of the marine environment, fishery activities, aquaculture and the maritime sector.

\section{Wageningen University \& Research:}

is specialised in the domain of healthy food and living environment.

\section{The Wageningen Marine Research vision}

'To explore the potential of marine nature to improve the quality of life'

\section{The Wageningen Marine Research mission}

- To conduct research with the aim of acquiring knowledge and offering advice on the sustainable management and use of marine and coastal areas.

- Wageningen Marine Research is an independent, leading scientific research institute

Wageningen Marine Research is part of the international knowledge organisation Wageningen UR (University \& Research centre). Within Wageningen UR, nine specialised research institutes of the Stichting Wageningen Research Foundation have joined forces with Wageningen University to help answer the most important questions in the domain of healthy food and living environment. 